\title{
CHARLES SPENCER CHAPLIN. TOMEMOS AIRE EN ESTOS TIEMPOS Y DISFRUTEMOS RECORDÁNDOLO
}

\section{CHARLES SPENCER CHAPLIN. TAKE AIR IN THESE TIMES AND ENJOY REMEMBERING}

Susana Salcedo Peris: Universidad Complutense de Madrid. (España) susalpe@hotmail.com

\section{CURRÍCULUM VITAE}

Licenciada en Comunicación Audiovisual por la Facultad de Ciencias de la Información de la Universidad Complutense de Madrid (España). Miembro de Fórum XII de Comunicación y Relaciones Públicas y de la SEECI (Sociedad Española de Estudios de la Comunicación Iberoamericana)

\section{RESUMEN}

Charles Spencer Chaplin, en una época de necesidad de evadirse del contexto social en el que el mundo se encontraba, sobresalió no sólo por su gran talento innato en el humor interpretativo, sino también porque el resto de su generación de humoristas, no alcanzaban su nivel y se quedaban en una simplicidad excesiva. La gran virtud de su cine fue convertir el humor en un idioma universal, en el que las palabras fuesen los sentimientos que sus imágenes nos hacían sentir. Por ello queremos hacer un repaso de su legado, destacando sus mejores momentos. 


\title{
PALABRAS CLAVE
}

Chaplin - Humor - Contexto Social

\begin{abstract}
Charles Spencer Chaplin, in a time of need to escape the social context in which the world was, not only excelled by his innate talent in humor interpretation, but also because the rest of his generation of comedians, did not reach the level and stayed in excessive simplicity. The great virtue of his films was to make the humor in a universal language in which the words are the feelings that made us feel their images. So we want to do a review of his legacy, emphasizing his best.
\end{abstract}

\section{KEY WORDS}

Chaplin - Humor - Social Context

\section{ÍNDICE}

\section{Introducción}

2. Contexto social

3. Tecnología del momento

4. Psicología gestual

5. 5. Relaciones de aspectos del humor gestual con épocas anteriores y posteriores a Charles Spencer Chaplin

6. Bibliografía

7. Filmografía analizada 


\section{TEXTO}

\section{Introducción}

Charles Spencer Chaplin (Londres, 16 de Abril de 1889 - Corsier-sur-Vevey, Sueiza, 25 de Diciembre de 1977, en una época de necesidad de evadirse del contexto social en el que el mundo se encontraba, sobresalió no sólo por su gran talento innato en el humor interpretativo, sino también porque el resto de su generación de humoristas, no alcanzaban su nivel y se quedaban en una simplicidad excesiva. La gran virtud de su cine fue convertir el humor en un idioma universal, en el que las palabras fuesen los sentimientos que sus imágenes nos hacían sentir. Con ello, no sólo traspasó todas las fronteras..., sino también el umbral del tiempo, donde muchos otros quedaron atrás y ya apenas se les recuerda. Hoy en día, el conjunto de sus obras a lo largo de su trayectoria de vida, es un legado de las situaciones que la población de aquel momento necesitaba ver reflejadas en pantalla, las cuales él caricaturizaba realizando así una crítica social tan tremenda que le costó finalmente su exilio de E.E.U.U.

\section{Contexto social}

Chaplin estudiaba minuciosamente el comportamiento de las diferentes clases sociales y como éstas se enfrentaban a la vida de distinta forma. Desde pequeño aprendió a imitar lo que observaba como única agradable distracción a las situaciones difíciles que le acontecían (el hambre, la ruptura de la familia...). Hizo de su hobby una profesión. Empezó acompañando a su madre en el teatro en números musicales. Con 5 años ya tenía una aparición fija. Su papel sobresaliente fue la imitación de un borracho que se situaba en el público. La respuesta de la gente en sus actuaciones le hizo entender lo que realmente la población demandaba. Una realidad revestida de un humor casi "infantil" que les permitiera reírse de sus propias 
desgracias y de las ajenas, burlarse del poder que los oprimía y de las vidas de lujo y riqueza que otros tenía a costa de los trabajadores a los que se les pagaba un sueldo mínimo y se les tachaba de inferiores. Querían una distracción. Un humor que les aportara no una simple risa, sino una RECONFORTANTE risa, y salieran del cine, dispuestos a sonreír porque Chaplin había dicho lo que el pueblo pensaba, lo que a ellos se les prohibía decir. Ejemplo:

Uno de sus grandes éxitos fue TIEMPOS MODERNOS. La película está llena de escenas que reflejan perfectamente el contexto social del momento. Destacamos una de ellas por considerarla determinante a la hora de entender su momento socioeconómico y socio-cultural. (Resumen de la historia) Charlot conoce a una mujer pobre que denominan en la película "la golfilla". Pero la conoce de una forma muy peculiar. Ella roba un pan y sale corriendo perseguida por la policía. Ambos se tropiezan en la calle en ese momento. La policía llega hasta ellos y él se autoinculpa del robo para dejarla escapar y, tras un revuelo en un coche, huyen juntos. Se paran en un jardín de una casa de una familia adinerada para descansar. Ven como el matrimonio que vive en esa casa, es feliz. La mujer se despide del marido con besos de verdadero amor y él se va a trabajar mientras ella lo ve irse con admiración. Vuelve dentro para encargarse de la casa. Charlot imita a la mujer adinerada, volviendo dentro feliz sin atender a los pobres que hay a la entrada de su casa. La imita casi burlándose de ella. Charlot le hace imaginar a la mujer pobre, cómo serían sus vidas si fueran de esa clase social. En ese sueño, los dos van vestidos con trajes caros y viven en una casa no demasiado grande en la que, para tener leche fresca, una vaca aparece en la puerta para ofrecérsela. Ella cocina un par de filetes de carne y se disponen a comer. Ahí acabaría ese sueño, volviendo a la realidad con las caras de hambre que ambos tienen. Deteniéndonos a analizar en concreto ese último momento en el que ambos sueñan su felicidad, se refleja perfectamente las grandes diferencias de clase social que había. Los ricos eran muy ricos y los pobres muy 
pobres. Y estos últimos soñaban con tener una vivienda, ropa y comida. Nada de hobbies ni sueños más allá de lo básico. En ese sueño actúan como imaginan que lo hacen las familias ricas, con posturas muy distinguidas que incluso llegan a parecer de personas redichas y engreídas si viéramos esas actitudes en personas que son realmente así. Con sonrisas ambos y posturas correctas, se sientan a una mesa para disfrutar de la comida, uniendo en el montaje el momento de cortar el filete con el momento de imitar cortarlo en la realidad y advertir juntos el hambre tan inmensa que tienen. Esa forma de imitar las actitudes de las personas que para ellos tienen "clase" (estirando todo el cuerpo al andar, ser todo menos natural, altivez, excesiva galantería..., etc), hace que no podamos más que reírnos de los intentos de la burguesía en demostrar constantemente que ellos siempre están por encima de los demás. La apariencia no es más que una imagen que queremos proyectar. Dista mucho de lo que somos en realidad. Chaplin hace denuncia social con su cine, y aquí lo demuestra. Quien aparenta es porque no confía en que ser natural sea... digamos... su punto fuerte. En cambio Charlot siempre es así. Con sus andares tan característicos de los pies separados y contoneando su cuerpo no para fingir galantería sino porque son sus andares propios, sus ingenuidades, sus sonrisas espontáneas, sus ganas de ayudar a los que como él, son despreciados por cualquiera que se crea con derecho a hacerlo, en definitiva, sus ganas de ser feliz. Son sus ganas las que lo mueven por la vida. Es un vagabundo en busca de la felicidad. 


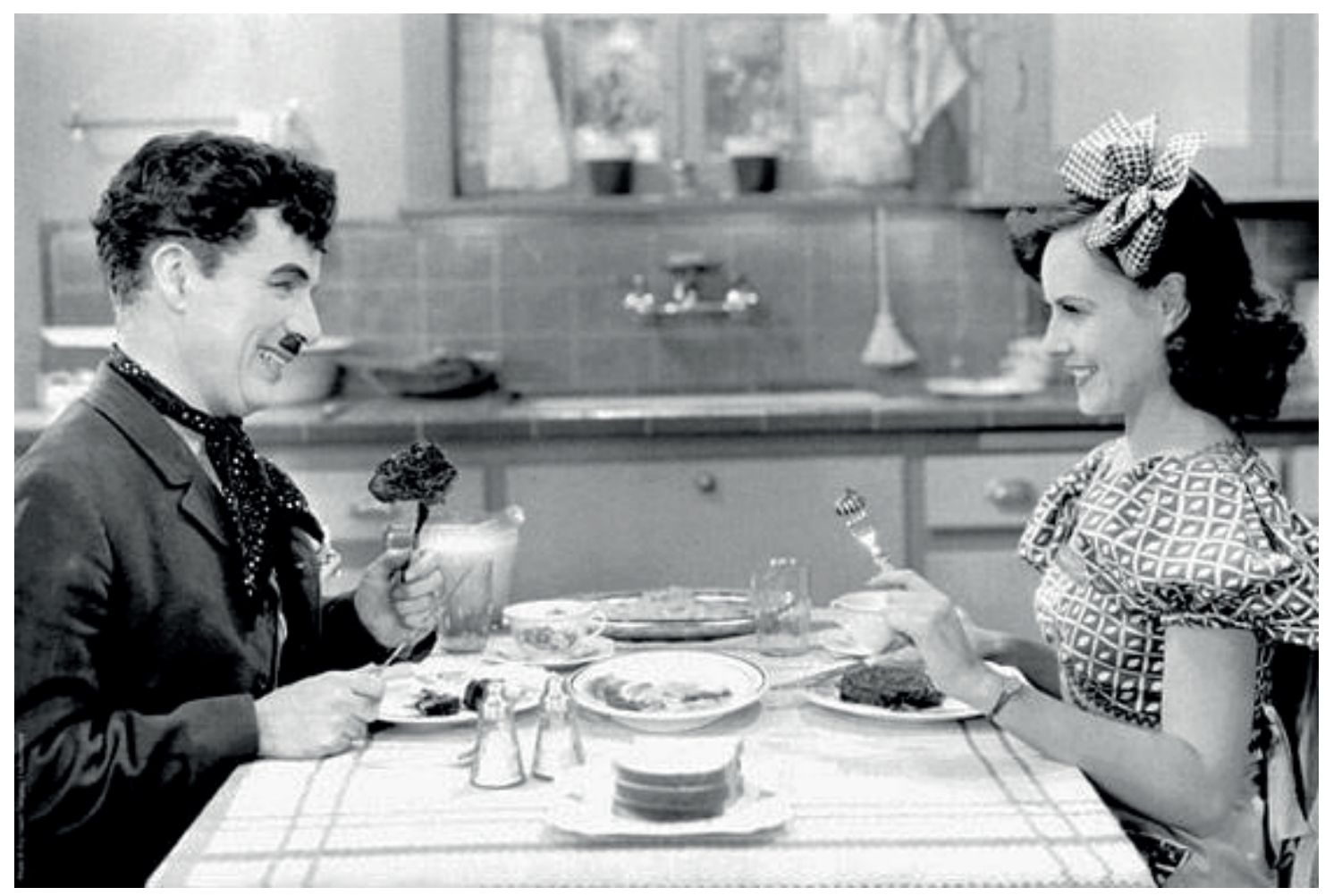

\section{Tecnología del momento}

En base a la tecnología desarrollada en aquel momento, Chaplin perfeccionaba su forma de llegar a las almas de todos los espectadores, introduciendo elementos que realmente enriquecieran su manera de interpretar.

Uno de esos elementos importantes es la caracterización del propio personaje, la personalidad del mismo. Recordemos que su primera interpretación cara al público fue la imitación cómica de un borracho. Éste llevaba una inconfundible indumentaria que le hacía encajar en el perfil de un burgués (sobrero, smoking, bigote...). Aunque también hay que decir que por aquel entonces, hacía muchas variantes de borrachos. Chaplin utilizó parte de esas típicas características para finalmente construir el personaje de Charlot que posteriormente hizo en prácticamente todas sus películas. Su smoking pasó a ser una chaqueta desgastada con la forma del smoking, y unos 
pantalones también desgastados al igual que sus zapatos. Dejó su bigote, le puso una caña como bastón y cambió el sombrero de copa por un bombín. Se colocó con los pies separados y con su talento echó a andar por el camino de la fama. Dotó al personaje, "Charlot", de una sensibilidad y humanidad poco corrientes en un mundo donde la mayoría de personas aceptaban insensibilizar sus corazones para poder ser egoístas con lo suyo. Hizo que Charlot siempre encontrase una salida a los problemas que le acontecían (o se dejase llevar por los que la encontraban), que él mismo provocaba o que gente que él quería, producía. Con Charlot vino la esperanza a las pantallas. Todo parecía tener una salida. Para él nunca era tarde para reconducir un mal comienzo. Esto es sólo en relación a "Charlot", pero siempre que Chaplin quería interpretar a cualquier otro personaje, su indumentaria cambiaba porque dejaba de ser el vagabundo que vive situaciones dispares, a ser cualquier otro personaje (Hittler por ejemplo), eso sí, nunca desprendiéndose de su peculiar bigote, para que no perdamos el rumbo de que sigue siendo una interpretación cómica.

Otro elemento positivo que hace potenciar su talento en la pantalla es la música que acompaña constantemente a la imagen. De esa forma incrementa considerablemente las emociones que la historia nos produce. Sólo contaba con ella (en la gran mayoría de sus películas) como único elemento en aquel momento para introducir a la par que la imagen, por lo que debía sustituir eficazmente al diálogo y así contarnos también con ella, todo lo que vemos (no sólo la imagen en movimiento, sino también los diálogos transcritos y textos explicativos que aparecían a lo largo de la película). 


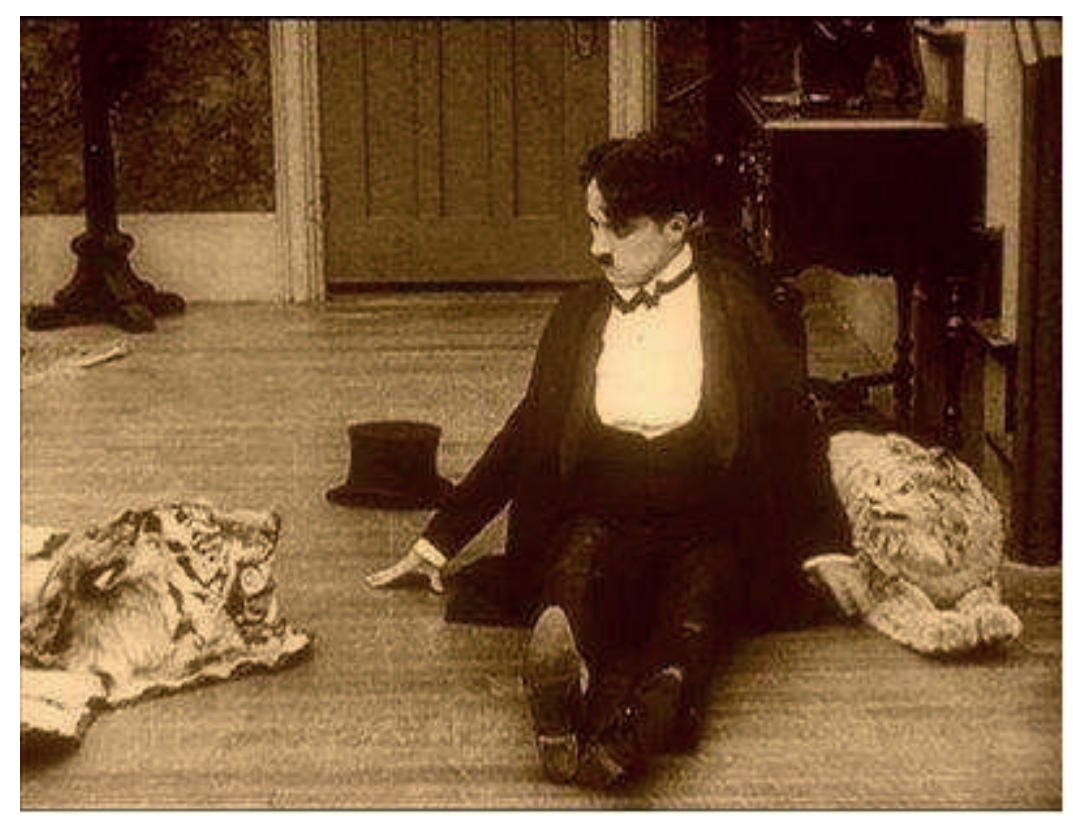




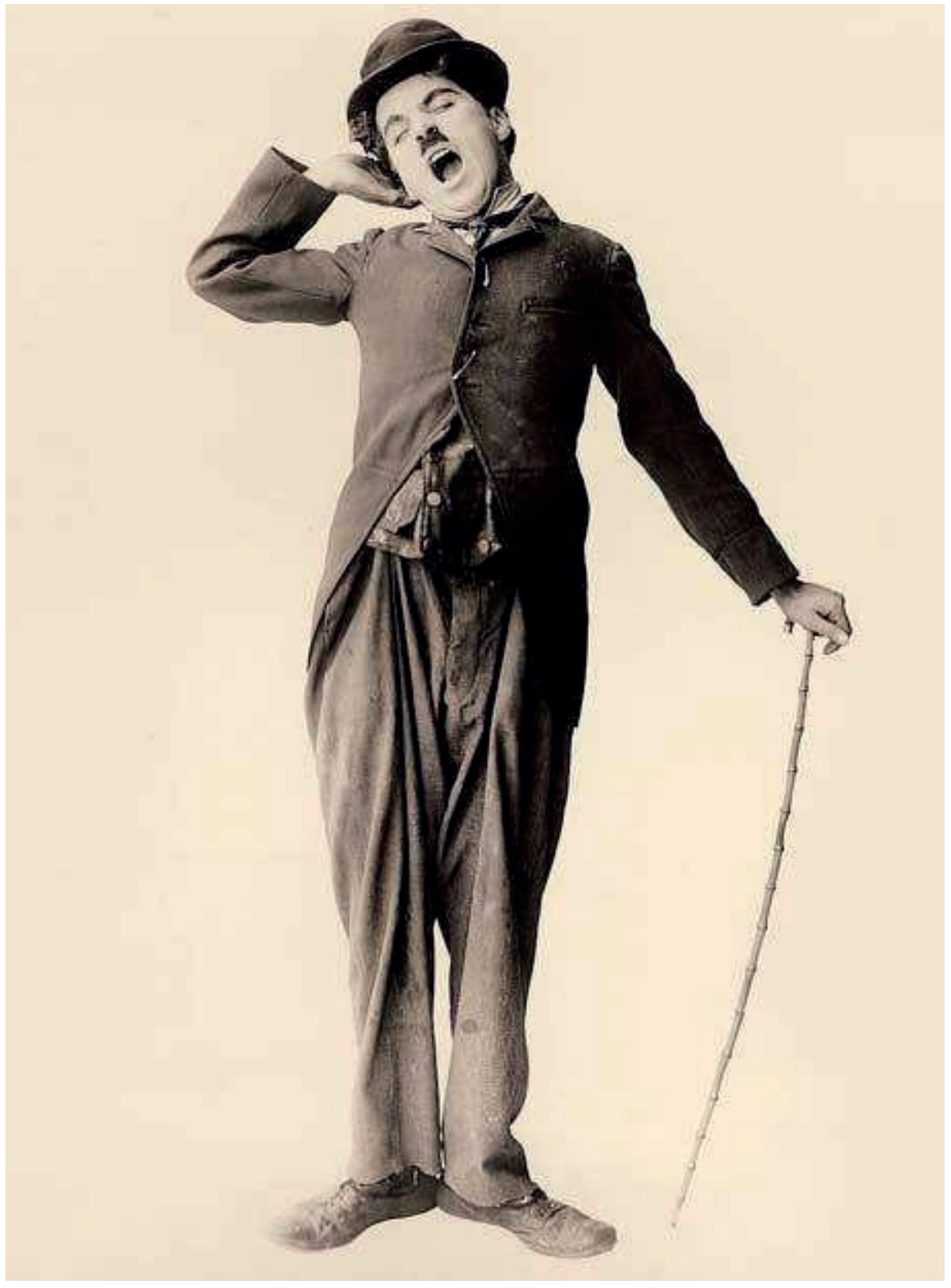

Otro de sus grandes éxitos fue EL CHICO. (Resumen de la historia) Y uno de los momentos más emotivos transcurre cuando "el chico", que no es hijo de Charlot pero que él lo trata como si lo fuera, es literalmente arrastrado del que era su hogar con Charlot, para pasar a manos de la autoridad. Charlot hace todo lo posible por mantenerlo a su lado, pero los hombres que vienen a por el niño se lo impiden y mediante la fuerza finalmente logra escapar de ellos y salir corriendo por los tejados 
en busca del coche que se lleva al niño. Al final conseguirá llegar. Analizándolo vemos la diferencia de vestuario tan grande que hay entre nuestro personaje y aquellos que vienen a por el chico. La clara diferencia de la postura de sus cuerpos. Las cabezas bien erguidas levantando la barbilla para marcar una distancia con el que tienen delante. No aparece ningún cartel de diálogo y es la música la que juega un papel fundamental. Va acorde perfectamente con el momento dramático que estamos viendo. Y la personalidad interpretada por todos ellos, está muy bien definida. Charlot incluso en estos momentos de especial delicadeza, no pierde su definición como personaje, y su modo de enfrentarse a los guardias y como huye de ellos podría hacernos reír porque sigue siendo él. Se tropieza, cae, pero siempre se vuelve a levantar, corre tras el coche por los tejados mientras los guardias siguen enzarzados en una pelea entre ellos creyendo que le están pegando a él, hasta que finalmente consigue llegar hasta su niño donde hace huir al conductor como lo haría cualquier padre. Aquí se demuestra que Charlot no es un simple personaje de comedia que te hace reír con sus caídas o porque se mete continuamente en líos. Es un personaje con sentimientos tan reales como lo que nos hace sentir y que se caiga o pelee exagerando las formas, deja de verse como una exageración, y pasa a ser la actitud de una persona real que vive una situación dramática. Es su personalidad y... ya jamás podrás verlo de otra forma.

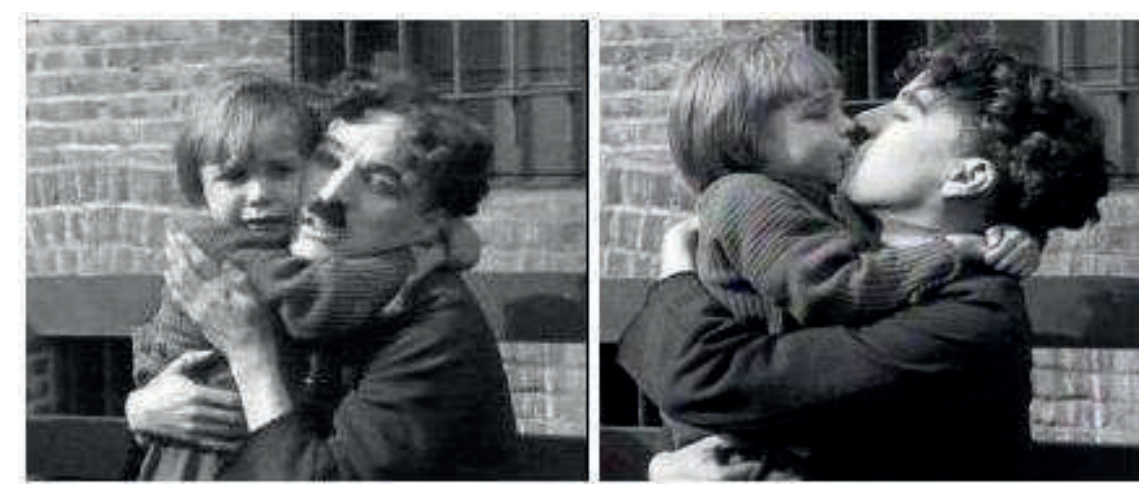




\section{Psicología Gestual}

Cualquier gesto que veamos en el otro, produce en nosotros una respuesta, y a la inversa. Esto quiere decir que mediante los gestos tenemos una conversación paralela a la verbal que nutre a ésta y la enriquece a la hora de entender cómo vemos al otro y lo que nos dice. El lenguaje verbal como tal, es simplemente mera información académica. El lenguaje gestual es el que permite entender esa información de la manera más correcta posible. Mediante los gestos del emisor y del receptor, sabemos de qué forma está transmitiendo el mensaje el emisor, a qué le da más importancia, qué quiere decir con él, que objetivos puede tener ese mensaje, cuál es su intención..., etc. Y por supuesto según los gestos del receptor, si éste entiende lo que le dicen, si no le gusta o si por el contrario responde con gestos de afirmación y entusiasmo ante la aceptación total del mensaje, también podemos saber si el mensaje no le interesa, si desea saber más..., etc. Como vemos, cuando hay un emisor y un receptor, todo parece seguir una línea de actuación en la que si estamos atentos podemos entender al otro. Charles Spencer Chaplin, supo de todo esto en su momento. ¿Cómo podía llegar al espectador si no sabía la respuesta que producían, en ese mismo momento, sus interpretaciones a medida que las iba haciendo? Por eso, como dijimos, analizó el contexto del momento y le dio al público lo que necesitaba. Sus únicas armas para llegar hasta ellos, eran sus gestos, y que con ellos se entendiera todo. Es por ello que la respuesta del público a lo que él hacía, muchas veces era exactamente lo mismo que Chaplin hacía reflejar en un personaje en la pantalla. Analicemos esto mejor. Él buscaba una respuesta por parte del público, que no podía ver pero sí dirigir. Conducía los sentimientos hacía donde él quería y muchas veces utilizaba el comodín de reflejarlos en un personaje con el que nos identificásemos. 
Acotar un gesto es imposible. Poder definir dónde empieza uno y acaba éste cuando a la vez se pueden dar decenas de todos ellos entrelazados dando a entender algo en concreto y que en un instante cambian parte de ellos para dar a entender otra cosa completamente distinta..., nos llevaría por caminos complejos que quizá trate en otra ocasión. Pero sí podemos decir cuáles de esos gestos son más significativos que otros porque conducen hacia el espectador por el camino correcto para entenderlos. Para ello pondremos varios ejemplos en los que los gestos, con o sin carteles de los diálogos o con la llegada del sonoro a sus películas, transmiten de forma clara lo que Chaplin nos quiere decir, siempre exagerando esos gestos el grado justo para no salirse de la personalidad de Charlot y que su vez la sonrisa no desaparezca.

Otro de sus clásicos fue EL INMIGRANTE. En esta película destacamos una escena mítica: (Resumen de la historia) Chaplin, hambriento y sin dinero, encuentra una moneda en la acera mientras pasea. Con esa moneda podrá pagarse una comida caliente en un restaurante. Se la guarda en el bolsillo y entra en el restaurante que tiene justo al lado. Allí le sirven judías, pan, algo de beber... y cuando va a comprobar que tiene su moneda, descubre que no está. Su bolsillo tenía un agujero por el que cabía ésta y se esfumó. En ese momento, su cara refleja el verdadero pavor y vergüenza al saber que si sale de allí, tendrá que ser por la fuerza. Finalmente consigue una moneda que es la del propio camarero que se le mete por dentro del pantalón y sale por un camal. A partir de aquí entran en juego una serie de intentos por conseguir atrapar la moneda. Cuando por fin la tiene y paga con ella, la moneda es falsa. Luego pasan más cosas, pero hasta aquí es donde quería analizar. Destaquemos pues sus gestos más inconfundibles en esa secuencia para entender lo que Charlot está pasando y como con esos gestos es capaz de hacernos reír: Charlot encuentra la moneda en la acera. Su cara de extrañeza y asombro lo dice todo. Incluso se acerca a la moneda para comprobar que realmente la ha encontrado. La coge, la limpia con expresión de orgullo, sintiéndose afortunado la mete en su 
bolsillo y entra con aire apresurado al primer restaurante que encuentra. La forma de no creerse haberla encontrado, limpiarla cual tesoro y al introducirla en su bolsillo, subirse los pantalones para asegurar que no se pierda, y entrar apresuradamente al restaurante, da un aire de ingenuidad e inocencia tan grande que hace enganchar al público. Al entrar lo sientan al lado de un hombre y le ponen judías y café. El modo de servirle la comida es de un desprecio exagerado. La cara del camarero es agresiva y su complexión corpulenta produce intimidación. Charlot prueba el café y se quema el labio, y hace un aspaviento hacia atrás asustando al hombre que tiene al lado que lo mira con curiosidad, también disgustado porque le está estropeando su momento de relajación comiendo. Él sonríe quitándole importancia y se dispone a comer. Coge sus cubiertos y entre ellos los roza haciendo el gesto de afilarlos. Es una costumbre muy de los hogares pobres puesto que afilaban sus propios cubiertos con sus herramientas en casa. Se dispone a comer las judías y va una por una. Como para disfrutarlas. No queriendo que se acaben... pero tiene tanta hambre que al final, deja el tenedor, y con el cuchillo, que es más alargado, coge un montón de judías y se las mete en la boca. Su cara de placer no tiene límites. Se entrecierran sus ojos y su bigotillo se mueve dándonos a entender que saborea el momento, pero que tampoco se recrea demasiado porque quiere que rápidamente la siguiente "cucharada" (cuchillazo) vaya a la boca. Gira su cabeza hacia su derecha, y ve que en la otra mesa mirándole hay una antigua amiga a la que él ayudó cuando unos ladrones le robaron el bolso. Al mirarla, las judías que estaban encima de su cuchillo y dispuestas a introducirse en la boca de Chaplin, se meten en el café. Este gesto es especialmente característico del desconcierto. Ver a alguien que no esperas, a veces provoca las descoordinación de los movimientos que estabas haciendo o que se anticipen los que pensabas realizar.. El hombre que comía con él se ha ido disgustado, por lo que ahora hay sitio a su lado. Se levanta entusiasmado, su postura es abierta, los brazos abiertos, sonrisa enorme y de frente. La abraza y la lleva hasta su mesa. 


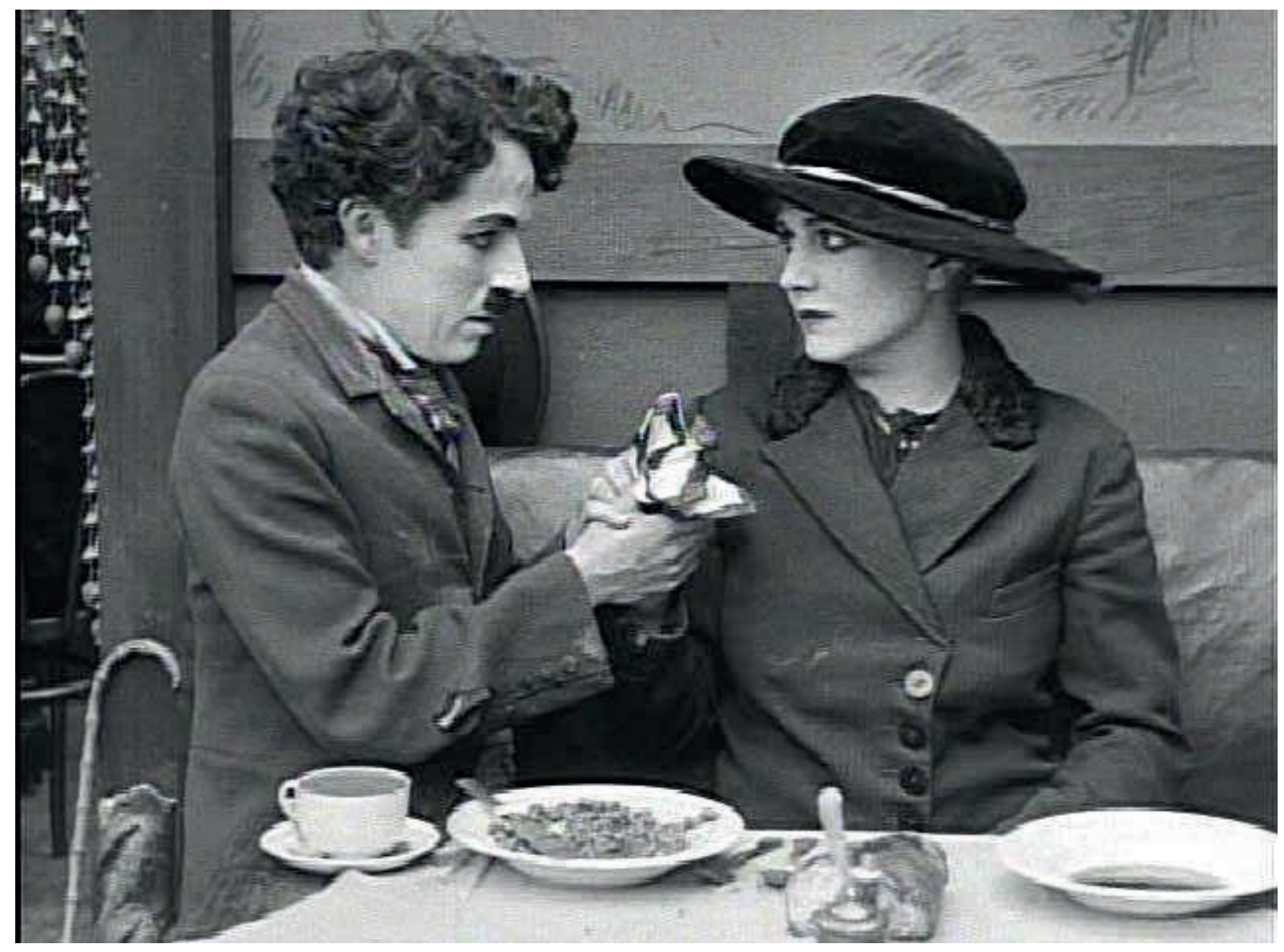

Pide comida para ella. Cada vez que se acerca el camarero, la cara de Charlot cambia a la seriedad, excepto cuando está haciendo alguna cosa y no quiere disgustarle, que entonces sonríe nerviosamente. Ve como un cliente es echado del restaurante como el que echaría a un pordiosero, sólo porque le faltaban 10 centavos. Él se asusta y decide comprobar su moneda pero no la encuentra. Su cara empieza a cambiar, su expresión a la de auténtico terror, y sus intentos por hallarla no dan sus frutos. Así que intenta imaginar cómo será la pelea que tendrá con el camarero, cierra sus puños y pelea en el aire moviendo la cabeza una y otra vez preparándose para la batalla. Ve entrar a un hombre con una moneda, asombrado de habérsela encontrado y comprende entonces Charlot, que es éste quien la tiene ahora, e intenta hacerle señas e incluso le tira comida para llamar su atención. No quiere tampoco enfrentarse al pobre hombre que acaba de entrar, pero si no lo hace lo sacarán de allí a puñetazos. 
No obstante, cada vez que intenta llegar hasta él, el camarero de enorme corpulencia le impide el paso al pasar por el pasillo. Él ve que es imposible quitársela y además, él también es un vagabundo que se ha encontrado una moneda, el mismo derecho tiene ahora sobre ella el nuevo vagabundo que la posee. Su cara refleja el desazón por la situación que vive..., pero en ese momento ve de nuevo una moneda en el suelo del restaurante, justo en mitad del pasillo. Él no lo ha visto, pero es una moneda que se guardó mal el camarero y que salió por su camal. Al verla en el suelo, abre la boca y levanta las cejas en señal de asombro, deja de tener las piernas cerradas y pisa con fuerza sobre la moneda para ponerla debajo de su zapato y que así nadie pueda quitársela, y vuelve a cruzar las piernas. Los músicos que están tocando se sobresaltan por ese ruido y el camarero va a ver qué pasa con cara todavía más disgustada. Charlot aparta el pie para coger la moneda pero entonces el camarero se pone encima. Charlot hace todo lo posible por recuperarla. Se pone la mano sobre las cejas haciendo la señal de avistamiento de algo a distancia para que así pueda apartarse de la moneda. Hace varios intentos distintos hasta que finalmente consigue hacerse con ella. Cuando va a pagar, el camarero comprueba si la moneda es verdadera o no, mordiéndola. Consigue doblarla y se la deja sobre la mesa diciéndole que es falsa. Charlot vuelve a tener un gesto de lo más característico y natural en su registro. Sus piernas se aflojan y se cae del asiento, y aunque el camarero lo vuelve a levantar como una pluma para dejarlo en su sitio de nuevo, vuelve a deslizarse del asiento porque no puede sostenerse. Finalmente conseguirá pagar la comida tanto de su amiga como la de él. La gracia está en que confluyan una serie de circunstancias que impidan a Charlot conseguir su propósito para que así él se las ingenie para conseguirlo. Es en esos momentos donde se despliega todo el arsenal carismático de Chaplin, quien acota perfectamente los momentos de entusiasmo, miedo, disgusto, tristeza..., y con apenas 3 carteles de diálogo y uno al principio explicativo que pone "Hambriento y cansado..." para que te sitúes en su circunstancia. 
No podemos olvidar otras escenas de TIEMPOS MODERNOS donde determinados gestos son especialmente claros y cómicos a la vez. Un buen ejemplo es cuando Charlot está en la fábrica y pierde el aparente control que tenía. Con sus gestos nos indica que es un hombre mecanizado que ha perdido su capacidad para pensar en otra cosa que no sea apretar tuercas, ya que él en la fábrica tenía esa función. Incluso todo lo que tiene forma de tuerca como son, (como aparece en la película) los botones de los trajes de las mujeres, arde en deseos de apretarlos. Los gestos son muy claros y su mensaje también. Hombre convertido en máquina en el que no hay cabida para los sentimientos humanos y es precisamente por eso por lo que entran en conflicto en su interior lo que es y lo que le obligan a ser. Son gestos de un auténtico irracional compulsivo con tics nerviosos, que explota después de haber sido tratado durante mucho tiempo como una máquina y que ahora sólo sigue concentrado en hacer bien su trabajo ya sea apretar las tuercas o lo que él considera en su mente de máquina, que lo son. Se mete entre los engranajes de la fábrica y provoca un caos allí tremendo. Vemos una situación surrealista, que sabemos que no pasaría en la vida real de esa forma, pero que se le acerca muchísimo a lo que sienten los trabajadores de las fábricas. La psicología de los gestos es siempre muy clara en sus películas. No admite dudas.

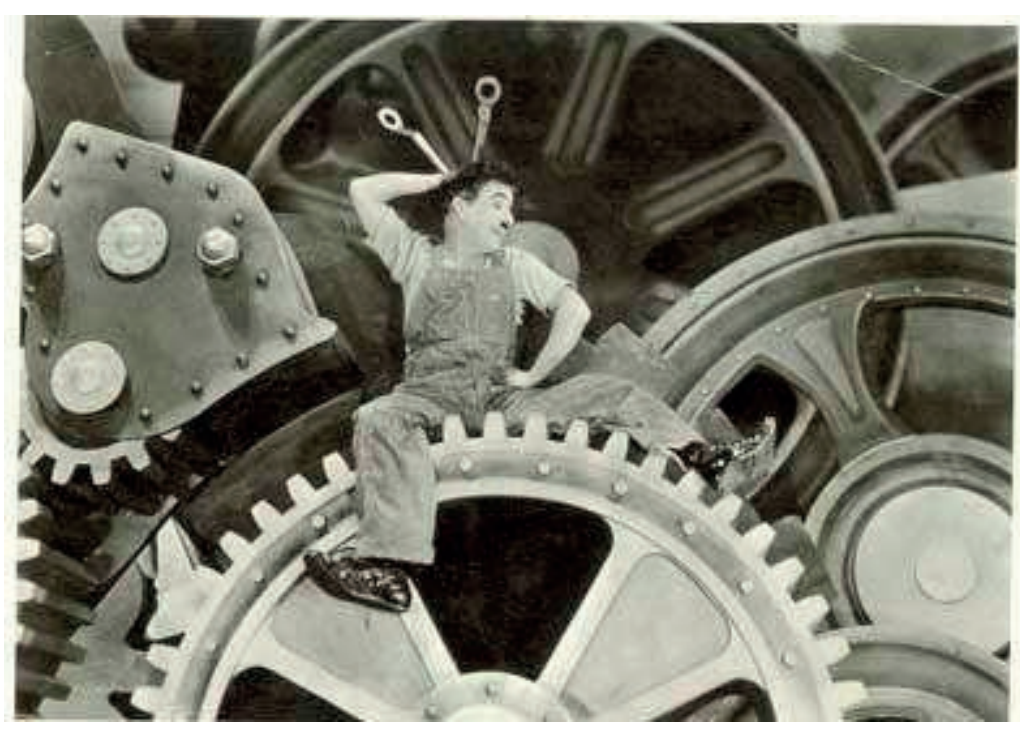


Otro buen ejemplo de esta misma película es cuando Charlot va a la cárcel y un traficante de cocaína, para salvar su pellejo, pone ésta en un salero del que luego se servirá Charlot, que quedará drogado durante varios minutos. Su expresiva cara a medida que va comiendo e introduciéndose por tanto, la droga en su cuerpo, refleja la sorpresa por sentir algo extraño en su organismo que no le disgusta para nada, más bien todo lo contrario. Ojos bien abiertos, sonrisa permanente, desacompasado en los movimientos y completamente en otra onda. Con pequeños toque como estos, sabes reconocer que está drogado. $\mathrm{Y}$ evidentemente todos esos gestos dentro de un contexto en el que lo que hace es humor, y es Charlot.

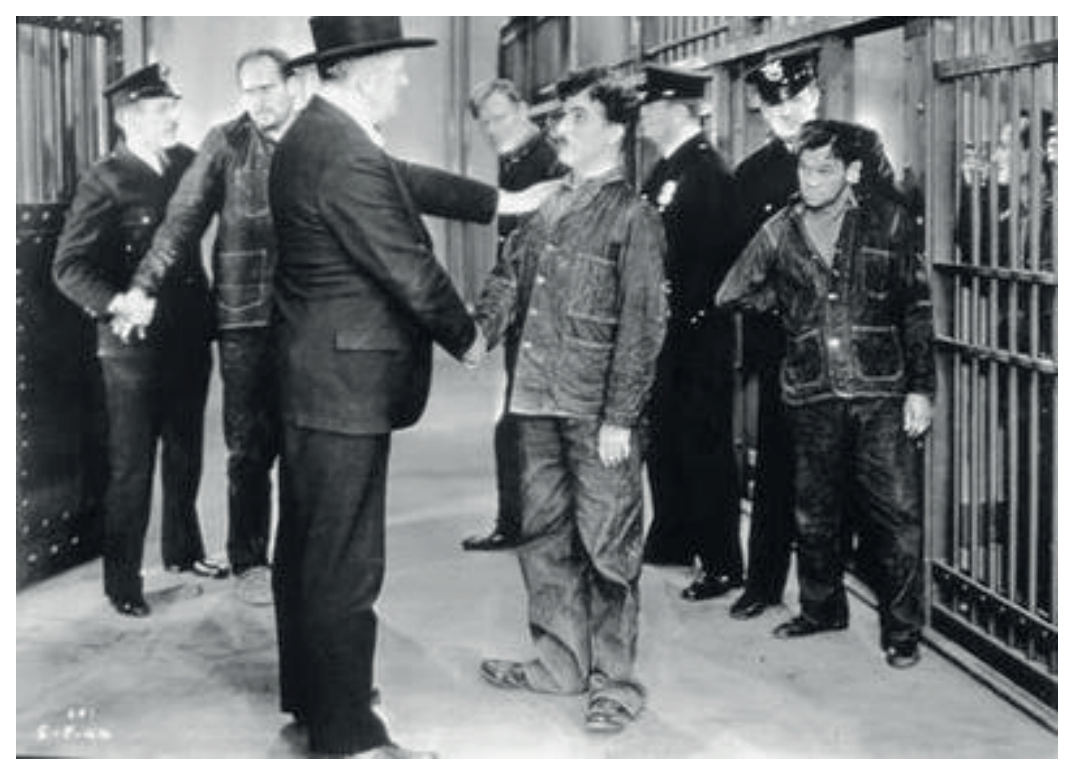

Tampoco podemos olvidar en EL GRAN DICTADOR algunas escenas míticas que han pasado a la historia por ser grito irónico y burlón al poder. 


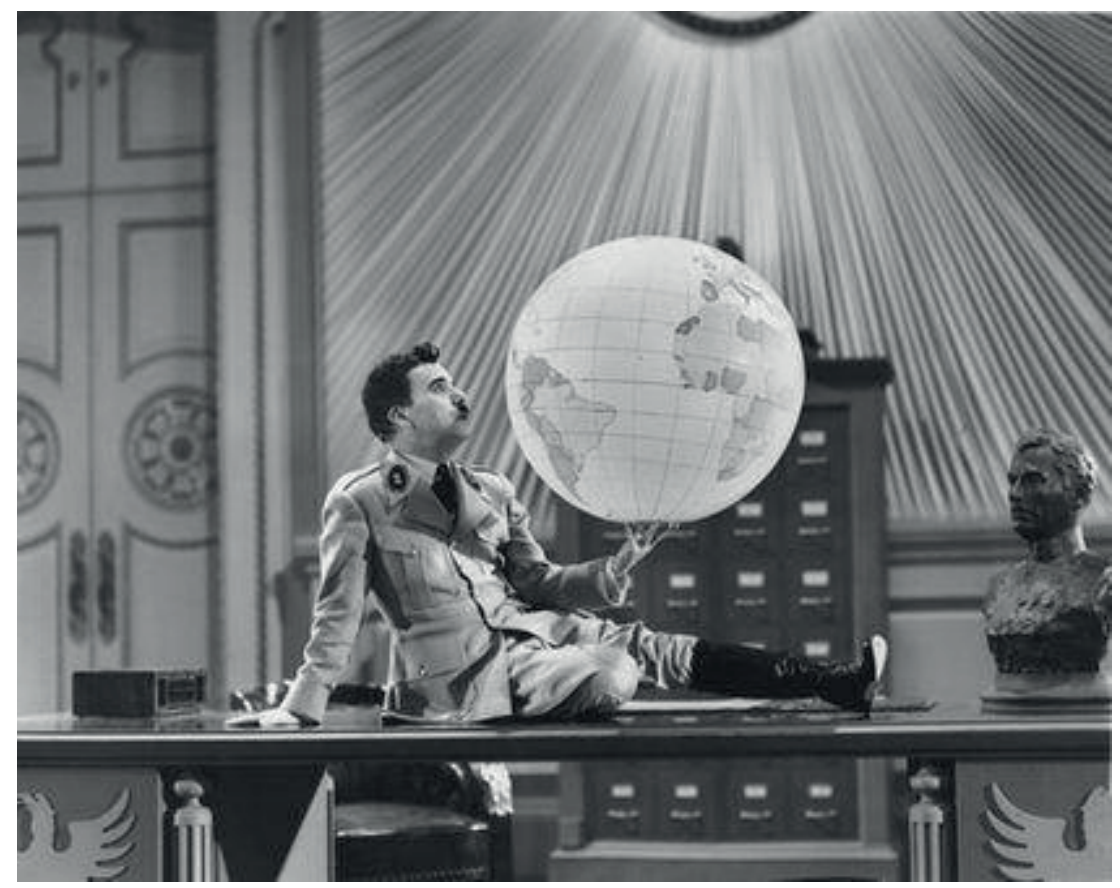

Hablamos pues, del momento en el que Hinkel (para recordar a Hitler), se cree dueño y señor del mundo, no porque ya todo esté en su poder, sino por la posibilidad tan grande, según cree, de poder dominarlo. Se queda solo en su despacho, y coge la bola del mundo, que es un globo de aire, y juega con ella a elevarla y a cogerla de nuevo sintiéndose dueño y señor de la tierra. Hay un momento en el que hace elevar a la bola del mundo dándole un empujoncito con su trasero (como burlándose de él). Al final, la bola del mundo acaba por pincharse y llora desconsoladamente sobre la mesa de su despacho. Sus gestos de una delicadeza y sensibilidad extremas son un baile a la ironía y burla hacia todos los dictadores. En palabras textuales de Chaplin: "Mi dictador tiene cierto parecido a Hitler. Es una coincidencia que use bigote como el mío, pero yo lo usé primero. Yo no remedo a ese individuo; no me presento con un rizo sobre el ojo. He tratado de hacer un resumen de todos los dictadores. No hay actor que no haya soñado con interpretar a Napoleón. Yo interpreto a la vez a Napoleón y a Hitler, al loco zar Pablo, a todos en uno" 
Otra escena en la que el lenguaje gestual es esencial, es en LA QUIMERA DEL ORO. Hay una escena que queremos destacar por ser una crítica social muy poderosa, y que consigue mediante los gestos, ni una sola palabra ni ningún cartel explicativo, hacerse entender. Hablamos del momento en el que Charlot y otro montañero que encontró en una escalada, comen juntos en su casa. Aquí se refleja muy bien el hambre que pasan los protagonistas. Charlot cocina su zapato y lo sirve a la mesa cual delicioso pescado. Actúa como la cosa más normal, ya que no tienen otra cosa que llevarse a la boca. El surrealismo del momento, hace cuerdo a su compañero que lo mira con extrañeza. No obstante, Charlot parece contento con su planto... la mitad de un delicioso pescado (la mitad de un zapato con clavos), que disfruta rechupeteando las espinas (los clavos del mismo), y sus moyas (la suela del zapato). Es una crítica social al momento, muy clara y sin ninguna duda. Destacamos la mirada del compañero que finalmente accede a comerse el zapato sin ninguna cara más allá que la sorpresa de que el zapato parece que es comestible y que no sabe demasiado mal. Y por supuesto la actitud de Chaplin, dispuesto a comerse gustoso su zapato, si es lo único que puede llevarse a la boca. Su cara no es de excesiva felicidad, pero si de un conformismo estremecedor ante la situación que vive

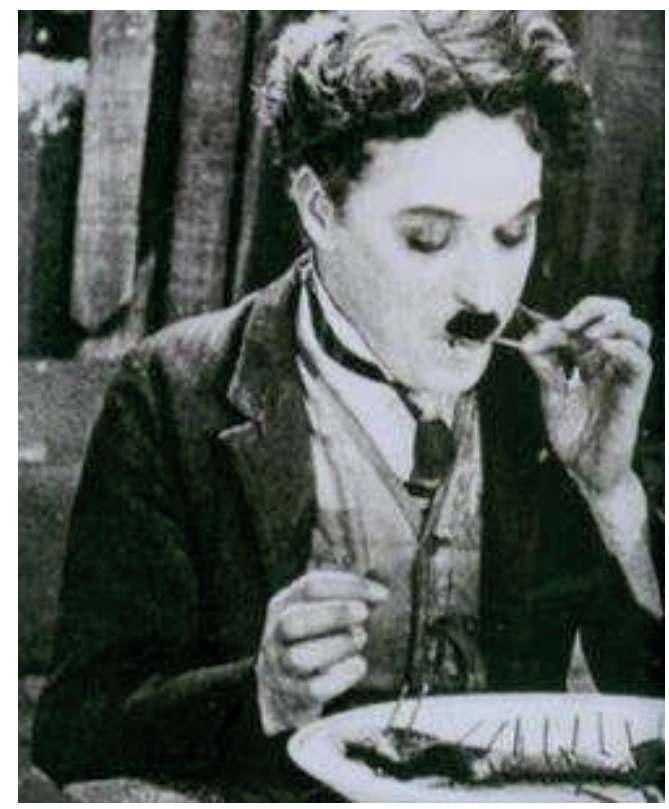


Destacar ahora, de LUCES DE LA CIUDAD, una escena muy famosa y muy gestual.Es una escena en la que vemos como Charlot transforma el boxeo en pura comicidad. La forma de moverse dando saltitos junto con el otro boxeador y el árbitro, la forma que tiene de escabullirse de los puñetazos del contrario abrazándolo continuamente, la forma de darlos él..., es un "querer hacerlo bien" pero siendo Charlot, que una vez que sabemos cómo es su personalidad, entendemos siempre la forma en la que se enfrenta a las cosas. Destacamos no sólo su papel, sino también el del contrincante que hace muy bien de atontao cuando le dan un golpe, no coordinando bien los movimientos y quedándose paralizado aunque no estático totalmente, ya que parece un muelle mientras Charlot intenta hacerse con él.

\section{Relaciones de aspectos del humor gestual con épocas anteriores y posteriores a Charles Spencer Chaplin}

Lo que hace verdaderamente grande a un humorista es que, en su conjunto, los personajes creados por él consigan sentar un precedente en cuanto a caracterización... ¿Pero, el vagabundo surgió de la mente de Chaplin como si nada o bien él también bebió de elementos del pasado? El bombín, los pantalones, la chaqueta, el bastón...si nos paramos a pensar, podemos llegar a la rápida conclusión que ésa nunca fue la manera de vestir de un vagabundo. Sino más bien de un vagabundo que quería ser algo más. Para crear este conjunto de vestuario tan mítico, Chaplin retrocedió a cuando él era un niño. Londres, finales del siglo XIX. La aristocracia está aún presente en Inglaterra, y muy fugazmente en la Inglaterra más mísera; y aquí es donde el pequeño Chaplin grabó a fuego en su memoria las vestiduras de estos aristócratas ingleses que muy de vez en cuando podía ver. Y no sólo eso, sino que también gracias al talento de su madre para interpretar (no olvidemos que ella era una gran actriz del mundo del teatro) e imitar los gestos de las personas, Chaplin consiguió adiestrar su agudeza visual y su talento en la parodia 
para hacer del gesto y de la imitación, o sea de la pantomima, uno de sus mejores recursos. Una vez triunfó con la anteriormente nombrada imitación del aristócrata borracho y dio el salto a Hollywood, comenzó a atisbarse en sus primeros cortos el que luego sería Charlot, y para ello realizó en su vestuario y en los gestos diversas modificaciones; en primer lugar, el borracho pasó a la historia ya que decidió que había emprendido una nueva etapa en su carrera y quería innovar con otro personaje. Para ello, cogió algún que otro elemento del borracho como fueron el bigote, las cejas gruesas y el pelo desgarbado. El comportamiento también debía cambiar, y en lugar de ser una persona rica sería una persona pobre con aspiraciones hacia la felicidad. Esto se vio reflejado en su elegante y mugrienta chaqueta y en esos pantalones bombacho, por no hablar del sombrero de hongo también mugriento y sus zapatos gigantescos que le darían ese aire patético y a la vez carismático. Los gestos en este sentido fueron fundamentales, aunque también sufrieron modificaciones a posteriori. Chaplin captó enseguida el ambiente de Hollywood, que era muy diferente al de la Inglaterra de la que él provenía. El Hollywood de los años 20 era un apogeo de estrellas del cine mudo y grandes atletas y bellas modelos convertidos a actores y actrices, y una opulencia que haría de la ciudad de Los Ángeles uno de sus signos más distintivos. Con lo cual, Charlie dedujo que lo que realmente triunfaría entre el público necesitado por entonces de humor e ideas nuevas, sería el ver a estas estrellas reflejadas en la pantalla de una manera patética a través de un comportamiento caricaturesco. Su gran amigo y también actor, Douglas Fairbanks, fue una de sus inspiraciones. En sus películas él era el héroe que salvaba a la dama en apuros, argumento explotado hasta la saciedad en las películas de la época. Chaplin le dio un giro radical y decidió que el comportamiento de este nuevo personaje fuese precisamente el de una especie de anti-héroe que casi es salvado por la propia dama en apuros. Sus gestos, sin embargo, denotaban una heroicidad inocente y cándida, casi infantil. Por tanto, acababa de dotar a su personaje de algo que ningún otro humorista en la Tierra había dado a sus creaciones; le había dado 
"corazón". En aquella época el cine mudo se resumía en el argumento anteriormente dicho pero reciclado a diversas situaciones (un barco pirata, un bar...), algo que Chaplin en cuanto tuvo control total sobre sus películas decidió que jamás haría. El conseguiría que el pequeño vagabundo fuese alguien con quien te gustaría charlar, alguien carismático, con un comportamiento perfectamente definido. Esto debía verse reflejado en sus gestos y su atuendo.

De hecho, el gesto más famoso de Charlot es su manera de andar con esos zapatones grotescos y su delgado bastón de caña. ¿Por qué alguien que se supone que ha de ser un héroe anda de una manera tan ridícula pero a la vez tan simpática? Nunca ningún héroe ha pretendido ser simpático, pero Chaplin lo es. Con lo cual la pregunta más lógica sería ¿Cómo demonios es posible que unos zapatos y un bastón puedan transmitir sentimientos al espectador? Y la respuesta no es otra que otorgándole al objeto o indumentaria una dependencia del personaje que lo lleva, adquiriendo por tanto los sentimientos que tenga en ese preciso momento; esto es, en el caso de Chaplin con su manera de andar, que el propio Charlot quisiera transmitirnos que está enfadado. En ese caso los zapatos se mueven en gestos rápidos y bruscos mientras clava su bastón contra el suelo para impulsarse. Si por ejemplo Chaplin estuviese alegre se moverían rápidamente pero de manera fluida y divertida, moviendo a su vez el bastón de forma eufórica. Por tanto llegamos a la conclusión de que la indumentaria que Chaplin dio a su personaje es también una extensión de sus gestos corporales.

Y desde el momento de su creación en adelante surgieron toda clase de imitadores que pretendían captar la esencia del humor de Chaplin, algo muy difícil de lograr ya que tanto su manera de andar, como de vestir, de comportarse, de reaccionar ante diversas situaciones... son única y exclusivamente de Charlot, el pequeño vagabundo. Y este pequeño gran personaje del cine de humor asentó unas bases que, 
además de los funestos imitadores anteriormente mencionados, adaptaron otros grandes de la comedia. El ejemplo más inmediato lo tenemos en los Hermanos Marx y concretamente en Groucho con su tosco bigote y su traje, aunque impecable, recuerda al de Charlot. Pero aquí termina el parecido, ya que el humor de los hermanos Marx era con una tendencia al absurdo. A continuación surgió en México un humorista que, no sólo en el bigote se parece (a pesar de que es menos grueso que el de Charlot) sino también en el hecho de que ambos pertenecen a estratos sociales inferiores y que son unos completos anti-héroes; hablamos de Cantinflas. La diferencia aquí reside en que el mejicano tenía el recurso sonoro (voz)y Charlot no (excepto en El Gran Dictador, el fin del personaje de Charlot), simplemente se valía de sus gestos y de la banda sonora entre otros elementos de la puesta en escena. Ya en el cine sonoro también hubo personajes con cierto parecido como por ejemplo el célebre inspector Clouseau de "La Pantera Rosa", con su bigote, jugando con el humor gestual además de la caracterización de su voz, lo cual lo hace un digno heredero de las bases humorísticas de Chaplin; sin embargo no pertenece a un estrato social bajo y las tramas de sus películas van encaminadas más al género policiaco con tendencia a la comedia.El humor del director Mel Brooks también debe mucho a este pequeño inglés, ya que en sus películas predominan los gags "silenciosos", utilizando únicamente el humor gestual que nos recuerda a Charlot; en este sentido, el norteamericano homenajeó en cierto modo esa influencia realizando una película en 1976 llamada "Silent Movie" que significa "película muda"(aquí mal traducida como "La última locura"), y que excepto efectos de sonido y música no existe ningún tipo de diálogo a lo largo de la película. De aquí en adelante los gags de las películas y las propias películas de comedia en sí mismas van haciéndose más sofisticadas dirigidas a un público que busca más el ingenio del diálogo. Sin embargo es en los momentos donde no existe diálogo y se da rienda suelta al humor gestual donde el espíritu de Charlot resurge. 
Esto sucede a partir de los años 90, y el ejemplo más claro lo encontramos en la película de 1993 llamada "Benny y Joon" en la que Johnny Depp interpreta a Sam, un personaje un tanto excéntrico. En cierto momento de la película, Sam comienza a juguetear con los panecillos en un restaurante y los clava en tenedores calcando la misma escena realizada por Chaplin en 1925 para "La Quimera del Oro". El homenaje es evidente. Y en una entrevista que concedió Johnny Depp para la reedición de las películas de Chaplin en DVD admitió que aquella escena en "Benny y Joon" le costó varios meses de ensayo con panecillos visionando la original de Chaplin para que pudiera parecerse "un poco". Éste no fue el único homenaje que Johnny hizo a uno de sus grandes ídolos, ya que también asemejó su forma de andar para su papel del capitán Jack Sparrow en la trilogía de "Piratas del Caribe", jugando a su vez con una gama de gestos que nos recuerdan al mejor Charlot.

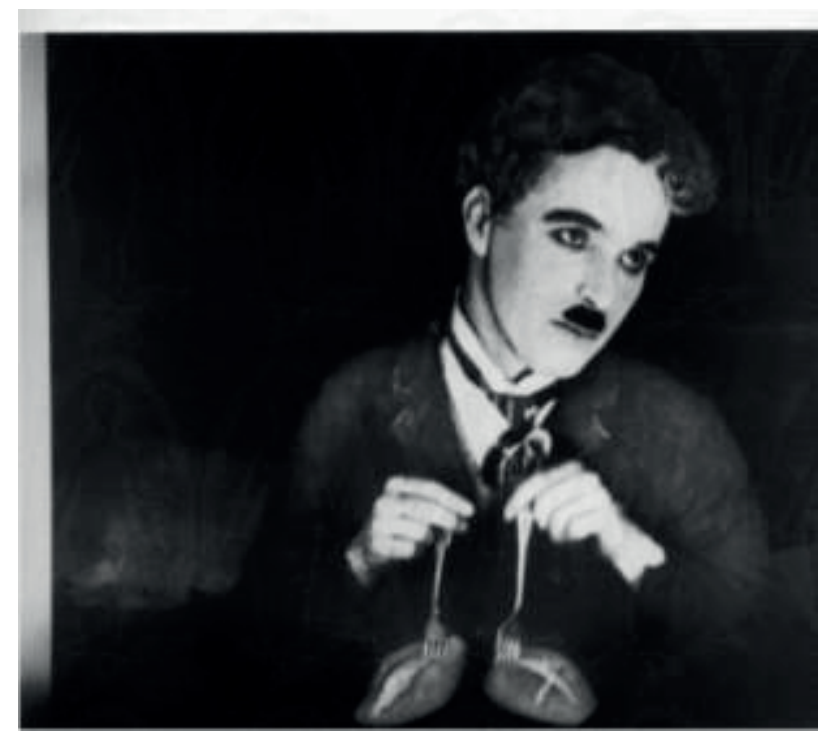




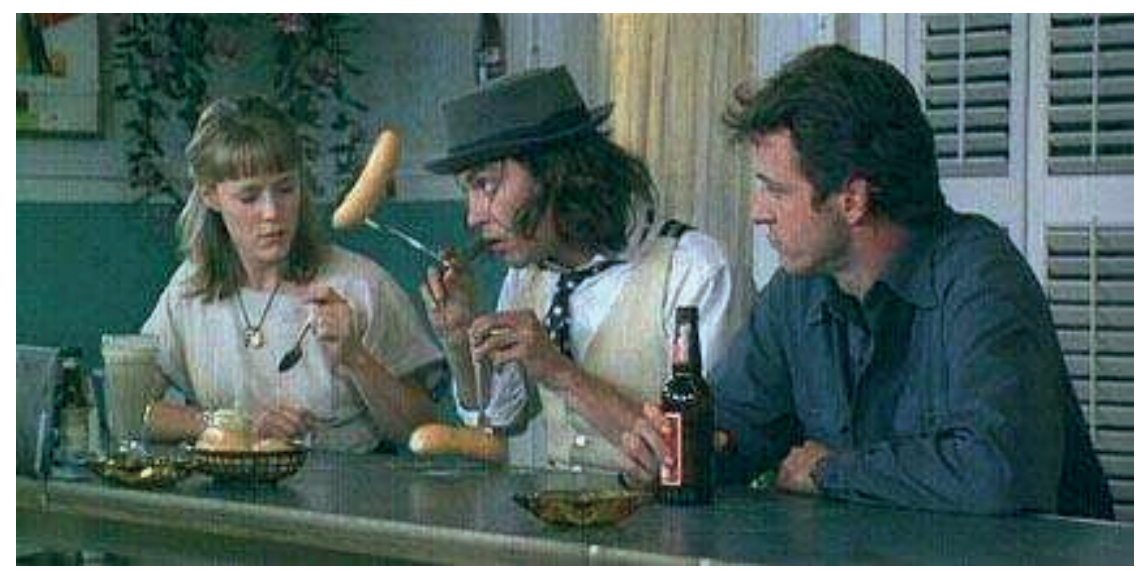

Pero las influencias del humor de Chaplin no terminan en el terreno de lo real, sino que traspasan al mundo virtual y de la animación de la mano de Pixar con "WALL E", en el que el personaje robótico que da nombre al título de la película no dice nada más que su propio nombre y el de su amada robot EVA. WALL E no está programado para nada más que reciclar los desechos que los seres humanos han dejado sobre la Tierra pero sin embargo cuando EVA aterriza, WALL E comienza a sentir algo parecido al amor. Todo esto sin necesidad de decir ni una palabra, pero conservando en todo momento el espíritu chaplinesco de anti-héroe ya que es el clásico argumento de las primeras películas de Charlot; el personaje vaga de aquí para allá hasta que de pronto se presenta la sofisticada dama que al principio no le presta demasiada atención. Él hace todo lo posible por conquistarla, luchando contra viento y marea por ella ante cualquier situación 


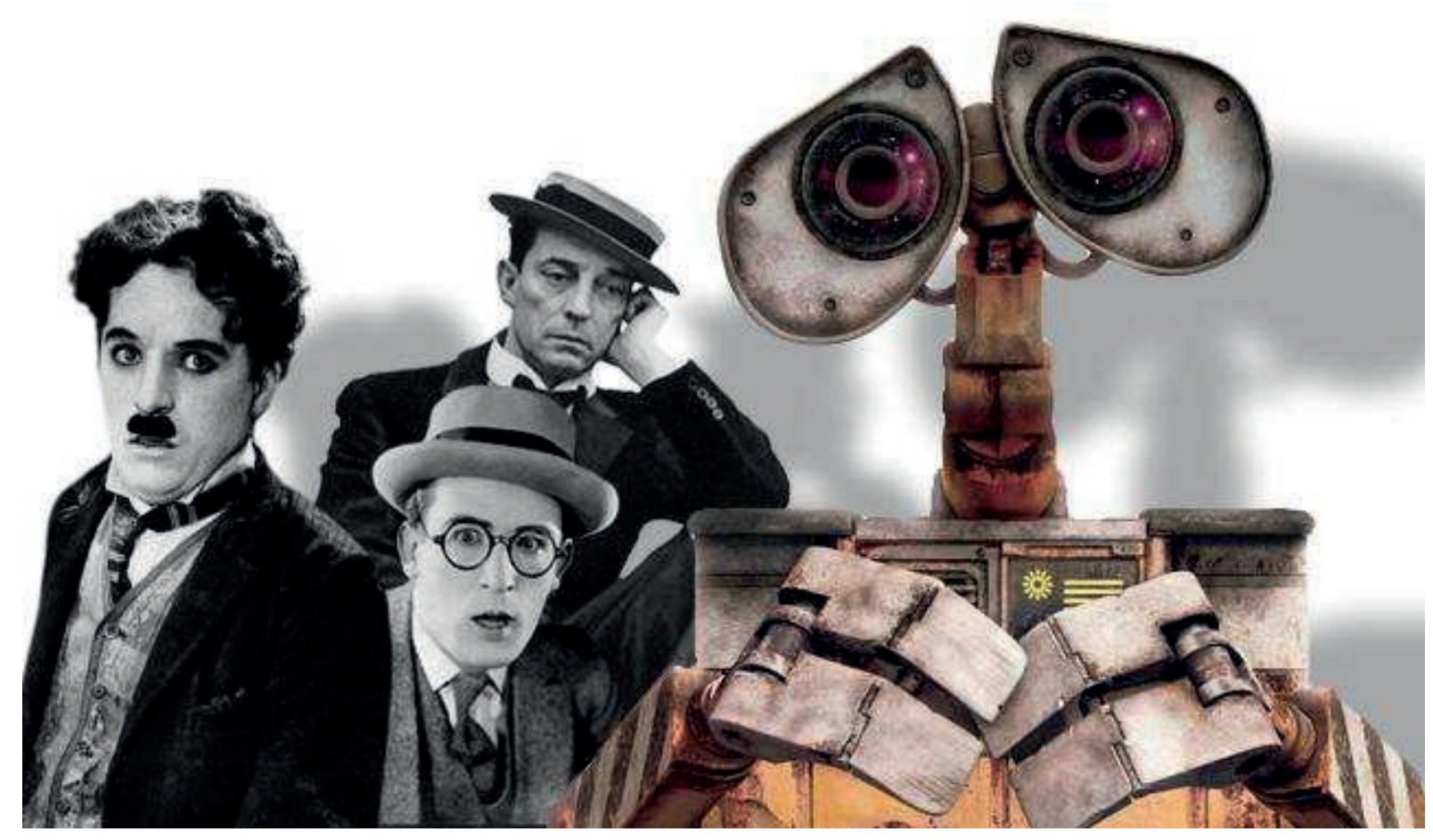

Éstos son sólo algunos de los ejemplos sobre quienes se han basado en el cine de Charles Spencer Chaplin. Pero con ellos nos podemos hacer una idea de todos los que hay y de los que habrá en un futuro.

El tiempo pasará y él seguirá siendo uno de los grandes, y su personaje "Charlot", un buen amigo con el que reírnos de las tristezas y afrontar las desidias con otro talante. Como dijo Chaplin "El tiempo es el mejor autor: siempre encuentra un final perfecto". 


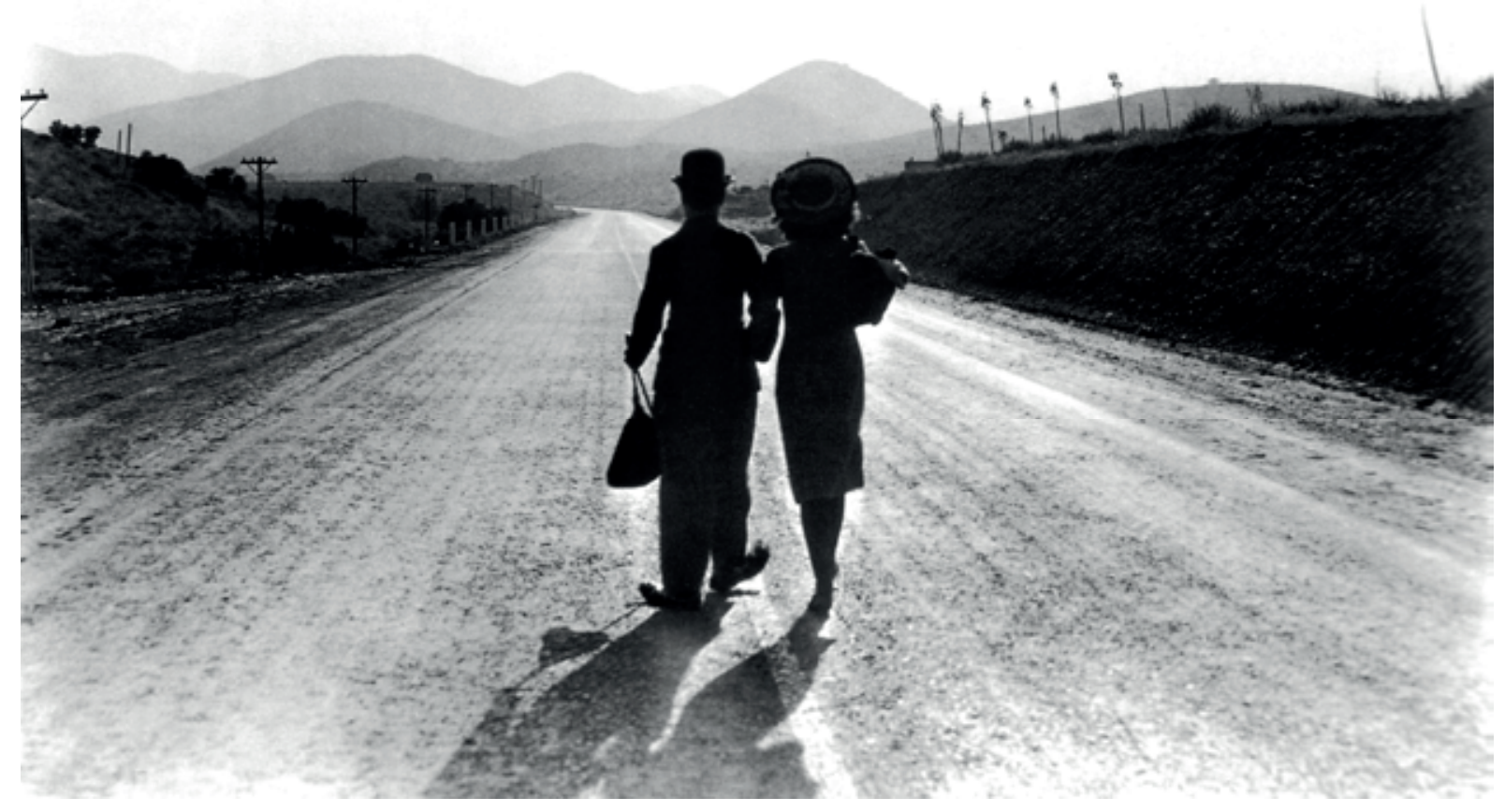

\section{Bibliografía}

“Charles Chaplin, el genio del cine” de Manuel Villegas López. 1998.

\section{Filmografía analizada}

“Charlie: vida y obra de Charles Chaplin”. El Mundo. Filmoteca de El Cultural. Colección.

ONE A.M.

7 de Agosto de 1916. Dos rollos.

ARGUMENTO Y DIRECCIÓN: Chales Chaplin 
INTÉRPRETES: Charles Chaplin (el noctámbulo), Albert Austin (el chófer del taxi).

FOTOGRAFÍA: Willian C. Foster y Roland Totheroh.

\section{EL INMIGRANTE}

17 de junio de 1917. Dos rollos.

ARGUMENTO Y DIRECCIÓN: Charles Chaplin.INTÉRPRETES: Charles Chaplin (el inmigrante), Edna Purviance (la inmigrante), Eric Campbell (jefe de camarero), etc. FOTOGAFÍA: William C. Foster y Roland Totheroh.

\section{EL CHICO}

6 de Febrero de 1921. Seis rollos.

ARGUMENTO Y DIRECCIÓN: Charles Chaplin.

INTÉRPRETES: Charles Chaplin (el vagabundo), Jackie Coogan (el chico), Sidney Chaplin (inspector de asistencia pública...), etc.

FOTOGRAFÍA: Roland Totheroh.

\section{LA QUIMERA DEL ORO}

16 de Agosto de 1925

ARGUMENTO Y DIRECCIÓN: Charles Chaplin.

INTÉRPRETES: Charles Chaplin (el buscador solitario), Mack Swain (el que se encuentra en la montaña), etc.

FOTOGRAFÍA: Roland Totheroh y Jack Wilson.

LUCES DE LA CIUDAD 
6 de Febrero de 1931.

ARGUMENTO Y DIRECCIÓN: Charles Chaplin.

INTÉRPRETES: Charles Chaplin (el vagabundo), Virginia Cherrill (la muchacha ciega), Hank Mann (el boxeador), Eddie Baker (árbitro), etc.

FOTOGRAFÍA: Roland Totheroh , Gordon Pollock y Mark Markblatt.

TIEMPOS MODERNOS

5 de Febrero de 1936.

ARGUMENTO, DIRECCIÓN, MÚSICA Y MONTAJE: Charles Chaplin.

INTÉRPRETES: Charles Chaplin (el vagabundo), Chester Conklin (un mecánico), Louis Natheaux (el cocainómano), etc.

FOTOGRAFÍA: Roland Totheroh e Ira Morgan.

EL GRAN DICTADOR

15 de Octubre de 1940.

ARGUMENTO Y DIRECCIÓN: Charles Chaplin.

INTÉRPRETES: Charles Chaplin (Hynkel, dictador), Charles Chaplin (un barbero judío), Paulette Goddard (Hannah), etc.

FOTOGRAFÍA: Karl Strauss y Roland Totheroh. 